\title{
Universitas
}

Review of

\section{ANALISIS PEMBANGUNAN INFRASTRUKTUR DAERAH TERHADAP PENDAPATAN ASLI DAERAH}

\author{
Lilis Setyowati*, Lukman Arya Himawan
}

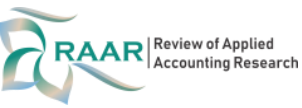

Affiliation:

Accounting Department, Universitas Dian Nuswantoro, Indonesia

\section{*Correspondence:}

lilis.setyowati@dsn.dinus.ac.id

Article Process:

Submitted:

September 18, 2021

Reviewed:

September 24, 2021

Revised:

October 4, 2021

Accepted:

October 9, 2021

Published:

October 10, 2021

\section{Citation:}

Setyowati, L., \& Himawan, L. A., (2021). Analisis

Pembangunan Infrastruktur Daerah Terhadap Pendapatan Asli Daerah. RAAR: Review of Applied Accounting Research, 1(2), 118-132.

\section{Office Address:}

Jl. K.H. Ahmad

Dahlan, Dukuhwaluh, Kec. Kembaran, Kabupaten Banyumas, Jawa Tengah 53182

e-ISSN : 2807-8969

\begin{abstract}
ABSTRAK
Tujuan dari penelitian ini untuk menganalisis jangka panjang dan jangka pendek yang terjadi antara pembangunan infrastruktur jalan, pembangunan infrastruktur pariwisata, pembangunan infrastruktur kesehatan dan pembangunan infrastruktur perdagangan terhadap pendapatan asli daerah pada Kota Semarang. Metode yang digunakan dalam penentuan sampel adalah cluster random sampling. Data diperoleh dari pendapatan asli daerah dan pengeluaran pembangunan infrastruktur yang dilaksanakan selama delapan tahun yaitu dari tahun 2012-2019. Hasil penelitian menunjukkan, pada jangka panjang dan jangka pendek pembangunan infrastruktur kesehatan dan pembangunan infrastruktur perdagangan lebih berkontribusi dan berpengaruh pada penerimaan pendapatan asli daerah, sedangkan pembangunan infrastruktur jalan dan pembangunan infrastruktur pariwisata tidak berkontribusi dan tidak terdapat pengaruh pada penerimaan pendapatan asli daerah.
\end{abstract}

Kata kunci: Pembangunan infrastruktur dan pendapatan asli daerah

\section{ABSTRACT}

The purpose of this study is to analyze the long-term and short-term between road infrastructure development, tourism infrastructure development, health infrastructure development, and trade infrastructure development to local revenue in Semarang City. The method used in determining the sample is cluster random sampling. The data is obtained from local revenue and infrastructure development expenditures for eight years, namely from 20122019. The results show that health infrastructure development and trade infrastructure development in the long and short term contribute more and affect local revenue. In contrast, road infrastructure development and tourism infrastructure development do not contribute and do not affect local revenue.

Keywords: Infrastructure development and Local revenue 


\section{PENDAHULUAN}

Ekonomi Indonesia dihantui oleh berbagai jurang insfrastruktur. Banyaknya tempat yang hanya memiliki infrsstruktur fisik dan digital dibawah standar atau mungkin bahkan tidak sama sekali, biasanya dikarenakan kurangnya investasi. Pertumbuhan, industrialisasi, dan urbanisasi yang begitu cepat dalam kurun waktu 20 tahun terakhir menyebabkan kebutuhan insfrastrukturpun semakin meningkat. Berbagai lapis pemerintahan di Indonesia selama beberapa periode kesulitan membangun insfrastruktur sesuai dengan laju tersebut. Hal ini dapat mengakibatkan pertumbuhan ekonomi dalam negeri dan integrase perdagangan dengan Kawasan Indo-Pasifik menjadi tidak maksimal. Selain dampak posisi geografis, pemerintah saat ini juga harus berhadapan dengan perlambatan ekonomi dan menurunnya pendapatan negara akibat pandemic COVID-19.

Salah satu hal yang dapat menghambat perekonomian pemerintah saat ini adalah lambatnya pembangunan insfrastruktur. Hal ini ditandai dengan kurangnya kualitas dan kuantitas insfrastruktur atau prasarana. Baik insfrastruktur fisik maupun non fisik, pemerintah nampaknya memiliki kesulitan untuk mendorong pengembangan struktural. Ketika keadaan insfrastruktur suatu daerah lemah, itu berarti bahwa perekonomiannya akan berjalan dengan cara yang sangat tidak efisien. Biaya logistik yang sangat tinggi, berujung pada perusahaan dan bisnis yang kekurangan daya saing, belum lagi dengan munculnya ketidakadilan sosial, seperti kesulitan yang dialami vagi sebagain penduduk untuk berkunjung ke fasilitas kesehatan, atau susahnya anak-anak pergi ke sekolah karena perjalanan yang masih susah atau mahal.

Penyebaran wabah COVID-19 telah membuat pemerintah di seluruh dunia mengeluarkan kebijakan untuk membatasi aktivitas di luar rumah. Kebijakan tersebut berdampak pada perekonomian nasional dan Jawa Tengah sehingga menyebabkan perekonomian Jawa Tengah tidak tumbuh sesuai kapasitasnya. Pertumbuhan ekonomi Provinsi Jawa Tengah pada triwulan I 2020 sebesar 2,6\% dimana capaian tersebut jauh lebih rendah dibandingkan pertumbuhan pada triwulan sebelumnya sebesar 5,34\%.

Kinerja perekonomian Jawa Tengah tersebut berada di bawah pertumbuhan ekonomi nasional dan Kawasan Jawa yang tercatat masing-masing sebesar 2,97\% dan 3,42\% (bps.go.id). Anggaran daerah merupakan suatu rencana dasar keuangan dalam pelaksanaan pelayanan publik. APBD dapat digunakan untuk pemerintah provinsi dan kabupaten/kota. Sebuah rencana keuangan setiap tahun pemerintahan daerah mulai dari 1 januari hingga 31 desember (satu periode), yang disetujui oleh pemerintah daerah dan DPRD berdasarkan Perda UU No 33 Tahun 2004. Secara umum struktur APBD meliputi pendapatan, belanja dan pembiayaan daerah. Diklasifikasikan berdasarkan urusan pemerintahan dan organisasi yang bertanggungjawab atas pelaksanaan sesuai dengan undang-undang.

Pembangunan infrastruktur merupakan aspek yang penting untuk mempercepat proses pembangunan nasional dan daerah (Purnama dan Azizah, 2019). Pembangunan

RAAR Vol.1 No.2 infrastruktur sebagai bentuk kemajuan perekonomian dan pendorong berkembangnya di sektor lain. Pembangunan infrastruktur menjadi fondasi yang kuat untuk pembangunan ekonomi yang berkelanjutan, dengan bertambahnya perbaikan infrastruktur yang dilakukan oleh pemerintah maka diharapkan akan menjadi bentuk kemajuan pertumbuhan ekonomi (Suratno, 2010). Selain itu infrastruktur juga berperan memberikan kontribusi terhadap 
pendapatan asli daerah. Anggaran Pendapatan dan Belanja Daerah (APBD) Provinsi Jawa Tengah mengalami peningkatan di tahun 2020. Anggaran pendapatan pemprov Jateng meningkat $7,44 \%$ dibandingkan tahun sebelumnya. Sementara anggaran belanja mengalami peningkatan sebesar 4,9\% dibandingkan tahun 2019 (bps.go.id).

Kota Semarang yang merupakan ibu kota Provinsi Jawa Tengah memiliki letak yang cukup strategis, mengakibatkan kepadatan pada jalur lintas seperti jalur lintas darat, laut, dan udara. Untuk memperbaiki jalur lintas darat dari kemacetan akibat jumlah kendaraan yang tidak seimbang, maka pembangunan infrastruktur jalan sangat diperhatikan. Tujuan pembangunan infrastruktur jalan untuk mendukung distribusi lalu lintas manusia maupun barang (Renstra Kementerian PU 2010-2014, 2010). Kemudahan akses akan memberi dampak positif untuk kelangsungan perekonomian di Kota Semarang. Infrastruktur jalan yang baik akan memberikan keunggulan bagi daerah, dalam bersaing secara kompetitif untuk memasarkan hasil produk daerahnya, perkembangan dan distribusi industrinya serta meningkatkan pendapatan daerah. Sedangkan, keterbatasan infrastruktur jalan dapat menghambat laju pertumbuhan ekonomi yang pada akhirnya menyebabkan harga suatu barang melambung tinggi. Selain itu efisiensi kota-kota dapat menurun akibat adanya kemacetan lalu lintas.

Infrastruktur potensial lainnya yang dijadikan sumber pendapatan daerah adalah pariwisata. Kota Semarang memiliki berbagai tempat wisata bersejarah seperti: Klenteng Sam Poo Kong, Masjid Agung Jawa Tengah, Gereja Blenduk dan Lawang Sewu. Pembangunan infrastruktur di pariwisata merupakan trobosan pemerintah untuk meningkatkan pendapatan ekonomi di daerah. Setiap daerah memiliki tempat wisata dari yang belum terpublikasi hingga sudah terpublikasi. Kota Yogyakarta merupakan sebuah daerah yang berhasil mengembangkan destinasi pariwisata sehingga menjadi keunggulan daerah tersebut (Pitana dan Gayatri, 2005:111).

Keberhasilan pembangunan pariwisata di Kota Yogyakarta tidak lepas peran pemerintah daerah sebagai penanggungjawab utama. Kota Semarang berupaya untuk membangun pariwisata guna meningkatkan pendapatan daerah. Beberapa tempat wisata belum dikelola dengan baik dan tidak optimalnya pemerintah daerah dalam pembangunan. Kota Semarang merupakan salah satu tujuan utama wisatawan yang hendak berkunjung ke Jawa Tengah. Pengelolaan tempat wisata yang kurang maksimal, tentu berpengaruh terhadap minimnya pemasukan untuk pendapatan daerah.

Infrastruktur Kesehatan berperan dalam menaikkan kualitas sumber daya manusia. Jika kualitas kesehatan baik, maka kualitas sumber daya manusia akan baik juga. Kualitas sumber daya manusia adalah hal penting dalam pembangunan negara maupun daerah. Pengadaan infrastruktur kesehatan, meliputi: pembangunan rumah sakit, pembangunan puskesmas, peningkatan fasilitas peningkatan sarana prasarana dan pengadaan peralatan kesehatan. Pada infrastruktur perdagangan ini berpotensial untuk dijadikan sebagai sumber pendapatan daerah dan sebagai trobosan pemerintah untuk memajukan perekonomian daerah. Namun, saat ini belum maksimal pengelolaan di infrastruktur perdagangan yang harus dioptimalkan pemerintah daerah.

Padahal, Kota Semarang minat beli masyarakatnya tinggi untuk belanja persediaan seharihari dengan harga yang terjangkau di pasar daripada di supermarket. Pengelolaan yang kurang maksimal, tentu saja akan berpengaruh terhadap sedikitnya pemasukan untuk pendapatan da erahnya. Tidak terlaksananya kegiatan pembangunan pasar tradisional, 
sebagai contoh pembangunan Pasar Karangayu dikarenakan adanya penolakan warga Kelurahan Karangayu tentang tempat relokasi sementara yang membuat pembangunan Pasar Karangayu belum dapat dilaksanakan. Sedikitnya pasar di Kota Semarang membuat minat masyarakat kurang untuk datang ke pasar untuk membeli kebutuhan sehari-hari.

Adanya peningkatan sarana dan prasarana infrastruktur di Kota Semarang diharapkan mampu untuk meningkatkan kondisi perekonomian. Dengan peningkatan kondisi pembangunan daerah akan meningkatkan kesejahteraan masyarakat dan terciptanya efisiensi dalam kegiatan perekonomian. Oleh karena itu upaya pembangunan ekonomi, pengembangan infrastruktur yang perlu untuk diperhatikan mengingat begitu pentingnya infrastruktur bagi pertumbuhan ekonomi daerah. Selain itu perlu adanya analisis mengenai perkembangan infastruktur untuk mencapai keberhasilan suatu pembangunan daerah tersebut. Soamale (2013) menyatakan bahwa pengeluaran pemerintah dan produk domestik regional bruto berpengaruh positif terhadap pendapatan asli daerah Kabupaten Kepulauan Sula. Lalu penelitian yang Fauji (2017) menyebutkan bahwa variabel belanja pemerintah di bidang pendidikan memiliki pengaruh positif dan signifikan terhadap pertumbuhan ekonomi, sedangkan variabel belanja pemerintah dibidang infrastruktur dan kesehatan tidak berpengaruh signifikan terhadap pertumbuhan ekonomi daerah.

Namun demikian menurut (Khalistyowati, 2017) penelitian yang dilakukan selama tiga tahun dari 2007 - 2009 hubungan secara keseluruhan menunjukkan infrastruktur pembangunan dengan pendapatan asli daerah sangat rendah. Demikian juga menurut (Abby, 2018) infrastruktur kesehatan dan pariwisata memiliki pengaruh negatif signifikan terhadap pendapatan asli daerah dalam jangka pendek dan jangka panjang, sedangkan untuk variabel infrastruktur jalan dan pertanian memiliki pengaruh yang positif signifikan terhadap pendapatan asli daerah dalam jangka pendek maupun jangka panjang. Adanya perbedaan penelitian sebelumnya, maka peneliti ingin melakukan penelitian kembali yang dilakukan oleh peneliti, Adapun penelitian ini dengan sebelumnya terletak pada objek penelitian akan dilakukan di Kota Semarang dan beberapa variabel yang berbeda yaitu mengenai infrastruktur jalan, infrastruktur pariwisata, infrastruktur kesehatan dan infrastruktur perdagangan.

\section{TINJAUAN PUSTAKA}

\section{Desentrasi Fiskal}

Secara konsep, desentralisasi yang dianut Indonesia termasuk devolusi yang secara teori akan membuat pemerintah daerah menjadi suatu pemerintahan yang otonom dan tidak terkait dengan level pemerintahan lain dalam negara. Akan tetapi, dalam kenyataannya pemerintah pusat dan pemerintah daerah terkadang berbagi wewenang terhadap fungsi yang tidak saling tumpeng tindih untuk menghasilkan total government (Seymour dan Turner, 2002). Dalam Undang-Undang Nomor 33 Tahun 2004 tentang perimbangan menjelaskan bahwa pemberian sumber keuangan negara kepada pemerintah daerah untuk desentralisasi memperhatikan stabilitas dan keseimbangan fiskal dan dalam penyelenggaraan desentralisasi dan dekonsentrasi.

RAAR Pembangunan merupakan salah satu upaya yang dilakukan secara terus-menerus untuk Vol.1 No.2 mendorong ke arah positif bagi kualitas kehidupan masyarakat. Menurut (Tjokroamidjojo, 1993) pembangunan adalah upaya masyarakat dalam perubahan sosial diberbagai bidang kehidupan menuju lebih baik dan maju. Menurut (Todaro dalam Bryant and White, 1982) 
pembangunan adalah proses multidemensi mencakup perubahan dalam struktur sosial, sikap-sikap rakyat dan lembaga nasional, pertumbuhan ekonomi, pengurangan kesenjangan dan pembatasan kemiskinan yang absolut. Berdasarkan definisi beberapa sumber tersebut dikatakan pembangunan suatu proses perubahan sosial yang secara sengaja bertujuan untuk meningkatkan taraf hidup sehingga terciptanya keadaan atau dinamika yang lebih baik.

Konsep pemberdayaan menurut (Prijono dan Pranarka, 1996) manusia adalah subjek bagi dirinya, dalam proses pemberdayaan adanya proses memberikan kemampuan kepada masyarakat menjadi berdaya, mendorong dan memotivasi individu sesuai kemampuan untuk menentukan pilihannya. Pemberdayaan harus ditujukan kepada kelompok maryarakat yang tertinggal, oleh sebab itu diperlukan adanya kepedulian yang diwujudkan dalam kebersamaan anatara pihak yang sudah maju dan yang belum berkembang.

\section{Pendapatan Asli Daerah}

Menurut (Elita, 2002) Pendapatan Asli Daerah adalah penerimaan yang didapat daerah dari sumber-sumber dalam wilayah yang dipungut berdasarkan undang-undang yang berlaku. Peranan pendapatan asli daerah itu sangat penting, karena pemerintah daerah diharapkan dapat mengurus dan mengelola rumah tangganya sendiri dengan penerimaan yang berasal dari daerah sendiri. Pendapatan asli daerah harus betul-betul dominan dalam melaksanakan otonomi daerah agar tidak dibiayai dari subsidi dan sumbangan pihak ketiga atau pinjaman daerah. Pendapatan Asli Daerah (PAD) adalah semua penerimaan daerah yang berasal dari sumber ekonomi asli daerah (Halim, 2004). Menurut Halim dan Nasir (2006:44), Pendapatan Asli Daerah adalah pendapatan yang diperoleh daerah dan dipungut berdasarkan peraturan perundang-undangan yang berlaku. Pendapatan Asli Daerah adalah penerimaan yang diperoleh dari sektor pajak daerah, retribusi daerah, hasil perusahaan milik daerah, hasil pengelolaan kekayaan daerah yang dipisahkan, dan lain-lain pendapatan asli daerah yang sah.

Menurut Permendagri Nomor 13 Tahun 2006 Pendapatan Asli Daerah dipisahkan menjadi empat jenis pendapatan, yaitu : pajak daerah, retribusi daerah, hasil perusahaan milik daerah, dan hasil pengelolaan daerah yang dipisahkan, dan lain-lain pendapatan asli daerah yang sah. Undang-undang nomor 32 tahun 2004 tentang Pemerintahan daerah dijelaskan bahwa sumber pendapatan daerah terdiri atas:

1. Pendapatan asli daerah, yang terdiri dari : hasil pajak daerah, hasil retribusi daerah, hasil perusahaan milik daerah, dan hasil pengelolaan kekayaan daerah yang dipisahkan, dan lain-lain pendapatan asli daerah yang sah

2. Dana perimbangan

3. Pinjaman daerah

4. Lain-lain pendapatan daerah yang asli.

Kemampuan daerah dalam melaksanakan otonominya sangat ditentukan atau tergantung dari sumber-sumber pendapatan asli daerah (PAD). Pemerintah daerah dituntut untuk dapat menghidupi dirinya sendiri dengan mengadakan pengelolaan terhadap potensi yang dimilik, untuk itu usaha untuk mendapatakan sumber dana yang tepat merupakan suatu keharusan. Terobosan-terobosan baru dalam memperoleh dana untuk membiayai pengeluaran pemerintah daerah harus dilakukan, salah satunya adalah sektor pariwisata.

\section{Infrastruktur Daerah}


pembuangan limbah, transportasi dan pelayanan-pelayanan similar untuk memfasilitasi tujuan-tujuan sosial dan ekonomi. Berdasarkan pengertian infrastruktur tersebut maka infrastruktur merupakan sistem fisik yang dibutuhkan untuk memenuhi kebutuhan dasar manusia dalam lingkup sosial dan ekonomi (Stone dalam Kodoatie, 2005).

Tujuan dari pembangunan adalah menciptakan daerah dengan memaksimalkan potensi yang ada didaerah, seperti: sumber daya alam atau pembangunan yang dapat meningkatkan pendapatan daerah. Untuk mencapai Good Governance pembangunan antar daerah perlu dilakukan dan peran masyarakat terdapatnya pemerataan dan keadilan tanpa ada campur tangan urusan yang tidak terkait. Dalam perencanaan pembangunan daerah seharusnya mencerminkan kebutuhan relitas suatu daerah, sebagaimana perencanaan pembangunan daerah tidak hanya dari daerah itu sendiri. Perencanaan berfungsi untuk memperbaiki penggunaan kembali sumber daya publik di daerah (Kuncoro, 2012).

\section{Pengambangan Hipotesis}

Pembangunan infrastruktur jalan bertujuan untuk mendukung distribusi lalu lintas manusia dan barang, serta membentuk struktur ruang wilayah. Dengan adanya perbaikan infrastruktur jalan yang baik akan memberikan keunggulan bagi sebuah negara maupun daerah untuk bersaing secara kompetitif dalam memasarkan hasil produknya dan mengembangkan industrinya. Semakin baik sarana dan prasana yang ada di jalan membuat meningkatkan pendapatan daerah dengan mudahnya distribusi antar daerah. Pembangunan infrastruktur jalan meliputi pembuatan jalan baru, pemeliharaan dan pelebaran jalan. Dampak adanya perbaikan infrastruktur jalan dapat meningkatkan laju pertumbuhan ekonomi disuatu daerah dengan semakin lancarnya jalur transportasi, maka dapatmeningkatkan pendapatan suatu daerah. Berdasarkan teori desentralisasi fiskal infrastruktur jalan berkaitan dengan peningkatan penerimaan daerah. Dalam penelitian (Harry, 2013) Infrastruktur jalan memiliki pengaruh positif terhadap peningkatan pertumbuhan ekonomi di Kota Sibolga. Begitu dengan penelitian (Ketut, 2016) bahwa pembangunan infrastruktur jalan memiliki pengaruh positif terhadap pertumbuhan PDRB. Sama halnya dengan penelitian (Abby, 2018) menunjukan hasil bahwa infrastruktur jalan berpengaruh positif terhadap Pendapatan Asli Daerah (PAD).

\section{H1 $_{1}$ : Infrastruktur jalan berpengaruh jangka panjang terhadap Pendapatan Asli Daerah}

Pembangunan infrastruktur pariwisata tidak lepas peran serta pemerintah sebagai penanggungjawab utama untuk berupaya membangun ekonomi daerah di sektor tersebut dan sebagai trobosan pemerintah meningkatan perekonomian. Pariwisata merupakan sektor potensial yang dapat dijadikan sumber pendapatan daerah. Pembangunan infrastruktur pariwisata meliputi pembangunan objek wisata baru, pengembangan wisata dan peningkatan sarana prasarana di wisata tersebut. Berdasarkan teori desentralisasi fiskal infrastruktur pariwisata bisa memperoleh pendapatan atau meningkatkan pendapatan daerah dengan banyaknya kunjungan wisatawan di Kota Semarang. Dalam penelitian (Ni komang, 2014) mengemukakan bahwa Jumlah kunjungan pariwisata memiliki pengaruh positif dan signifikan terhadap PAD.

\section{RAAR}

Vol.1 No.2

$\mathbf{H}_{2}$ : Infrastruktur pariwisata berpengaruh jangka panjang terhadap Pendapatan Asli Daerah

Pembangunan infrastruktur kesehatan merupakan hal yang dominan dalam menyumbang kualitas sumber daya manusia, dengan begitu semakin baik kualitas kesehatan akan membantu dalam pembangunan suatu daerah dan meningkatkan pendapatan di kesehatan. Pembangunan infrastruktur kesehatan meliputi pembangunan rumah sakit, 
perbaikan/perkembangan puskesmas dan peningkatan alat kesehatan. Berdasarkan teori desentralisasi fiskal infrastruktur kesehatan bisa untuk meningkatan penerimaan pendapatan daerah di Kota Semarang melalui sumber daya manusia yang semakin baik. Penelitian yang dilakukan (Nurudeen dan Usman, 2010) menyimpulkan bahwa belanja pemerintah di bidang kesehatan berpengaruh positif signifikan terhadap pertumbuhan ekonomi. Sama halnya dengan penelitian (Warsilan, 2015) Infrastruktur kesehatan berpengaruh signifikan terhadap pertumbuhan ekonomi Kota Samarinda. Maka hipotesis yang diajukan dalam penelitian ini adalah:

H3 : Infrastruktur kesehatan berpengaruh jangka panjang terhadap Pendapatan Asli Daerah

Pembangunan infrastruktur perdagangan merupakan sumber pendapatan daerah yang harus dimaskimalkan dan sebagai trobosan pemerintah untuk memajukan perekonomian. Dengan adanya peningkatan kondisi pembangunan daerah akan meningkatkan kesejahteraan masyarakat dan terciptanya efisiensi dalam kegiatan perekonomian. Pembangunan infrastruktur perdagangan meliputi pembuatan pasar tradisional yang baru, relokasi pasar dan perbaikan sarana prasarananya. Berdasarkan teori desentralisasi fiskal insfrastruktur perdagangan dapat berpengaruh untuk penerimaan daerah Kota Semarang dengan laju perekonomian yang seakin baik. Penelitian (Agus, 2009) menyatakan sektor perdagangan berkontribusi besar dalam pembangunan daerah.

H4 : Insfrastruktur perdagangan berpengaruh jangka panjang terhadap Pendapatan Asli Daerah

Dari uraian rumusan hipotesis diatas kerangka pemikiran penelitian ini dapat digambarkan seperti pada gambar di bawah ini:

\section{KERANGKA PEMIKIRAN}

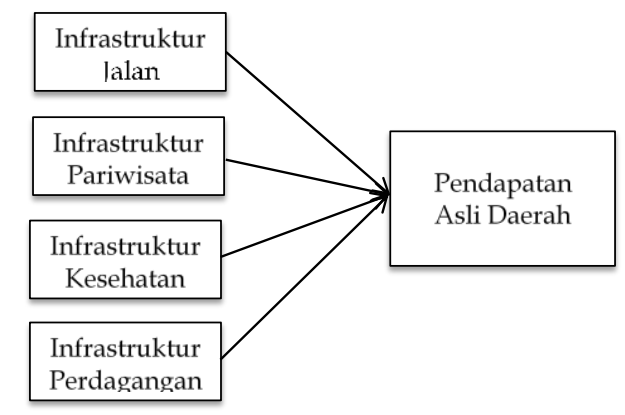

\section{METODE PENELITIAN}

Penelitian ini menggunakan metode cluster random sampling dalam menentukan sampel penelitiannya yaitu Teknik pengambilan sampel secara berkelompok pada area tertentu, untuk meneliti tentag sesuatu hal pada bagian-bagian di dalam suatu instansi. Jenis data peneliti adalah times series, berkaitan selama delapan tahun yaitu dari tahun 2012 - 2019 dengan menggunakan data triwulan per tahunnya. Jenis data yang digunakan penelitian ini adalah data sekunder yang telah diolah oleh pihak lain dan disajikan dalam bentuk tabel. Data diambil dari Badan Perencanaan Pembangunan Daerah (BAPPEDA) dan Badan Pengelolaan Keuangan dan Aset Daerah (BPKAD) Kota Semarang. Uji analisis yang 
digunakan dalam penelitian ini yaitu uji stasioneritas, uji kointegrasi, dan Error Correction Model (ECM).

\section{HASIL ANALISIS DAN PEMBAHASAN}

Tabel 1. Hasil uji Stasioneritas pada Tingkat Level

\begin{tabular}{llll}
\hline \multicolumn{1}{c}{ Variabel } & $\begin{array}{l}\text { Adj. } \\
\text { t-statistik }\end{array}$ & $\begin{array}{l}\text { Critical } \\
\text { Value } \\
(\alpha=5 \%)\end{array}$ & Prob. \\
\hline PAD (Y) & -2.423845 & -2.960411 & 0.1437 \\
\hline JALAN & -1.148322 & -2.960411 & 0.6835 \\
\hline PARIWISATA & -4.005256 & -2.960411 & 0.0043 \\
\hline KESEHATAN & -0.714470 & -2.960411 & 0.8286 \\
\hline PERDAGANGAN & -2.080585 & -2.960411 & 0.2534 \\
\hline
\end{tabular}

Dari tabel diatas dapat dilihat pada tingkat level untuk variabel infrastruktur pariwisata yang stasioner dengan nilai probabilitas $0,0043<0,05$. Kemudian terdapat empat variabel yang tidak stasioner pada tingkat level yaitu pendapatan asli daerah dengan nilai probabilitas $0,1437>0,05$, infrastruktur jalan dengan nilai probabilitas $0,6835>0,05$, lalu infrastruktur kesehatan dengan nilai probabilitas 0,8286>0,05 dan infrastruktur perdagangan dengan nilai probabilitas $0,2534>0,05$. Karena terdapat variabel yang tidak stasioner di tingkat level dengan signifikansi $\alpha=5 \%$, maka diperlukan uji akar unit pada tingkat derajat integrasi pertama (First Difference).

Tabel 2. Hasil uji Stasioneritas pada Tingkat First Difference

\begin{tabular}{llll}
\hline Variabel & $\begin{array}{l}\text { Adj. } \\
\text { t-statistik }\end{array}$ & $\begin{array}{l}\text { Critical Value } \\
(\alpha=5 \%)\end{array}$ & Prob. \\
\hline PAD (Y) & -10.62619 & -2.963972 & 0.0000 \\
\hline JALAN & -12.28795 & -2.963972 & 0.0000 \\
\hline PARIWISATA & -12.141381 & -2.963972 & 0.0000 \\
\hline KESEHATAN & -7.162412 & -2.963972 & 0.0000 \\
\hline PERDAGANGAN & -12.21429 & -2.963972 & 0.0000 \\
\hline
\end{tabular}

Dari tabel diatas dapat dilihat pada tingkat first difference semua variabel yaitu pendapatan asli daerah, infrastruktur jalan, infrastruktur pariwisata, infrastruktur kesehatan dan infrastruktur perdagangan menyatakan nilai probabilitas $0,0000<0,05(\alpha=5 \%)$ dengan begitu semua variabel sudah stasioner. Maka data tersebut bisa dilanjutkan kembali pada uji kointegrasi.

\section{Uji Kointegrasi}

Tabel 3. Hasil uji Kointegrasi Johansen

\section{RAAR}

Vol.1 No.2
Sample (adjusted): 2010Q3 2017Q4

Included observations: 30 after adjustments

Trend assumption: Linear deterministic trend

Series:
PARIWISATA
KESEHATAN 


\section{PERDAGANGAN}

Lags interval (in first differences): 1 to 1

Unrestricted Cointegration Rank Test (Trace)

\begin{tabular}{lclll}
\hline $\begin{array}{l}\text { Hypothesized } \\
\text { No. of CE(s) }\end{array}$ & Eigenvalue & $\begin{array}{l}\text { Trace } \\
\text { Statistic }\end{array}$ & $\begin{array}{l}0.05 \\
\text { Critical Value }\end{array}$ & Prob.** \\
\hline None $*$ & 0.743171 & 89.97451 & 69.81889 & 0.0006 \\
At most 1 $*$ & 0.574455 & 49.19417 & 47.85613 & 0.0372 \\
At most 2 & 0.437243 & 23.56266 & 29.79707 & 0.2195 \\
At most 3 & 0.189407 & 6.315422 & 15.49471 & 0.6583 \\
At most 4 & 0.000524 & 0.015736 & 3.841466 & 0.9000 \\
\hline
\end{tabular}

Trace test indicates 2 cointegrating eqn(s) at the 0.05 level

$*$ denotes rejection of the hypothesis at the 0.05 level

**MacKinnon-Haug-Michelis (1999) p-values

Hasil uji kointegrasi menunjukan nilai Eigenvalue sebesar 0,743171 dengan Trace Statistic sebesar 89,97451 lebih besar dari Critical Value pada tingkat level $(\alpha=5 \%)$ sebesar 69,81889. Dapat disimpulkan bahwa variabel pendapatan asli daerah, infrastruktur jalan, infrastuktur pariwisata, infrastruktur kesehatan dan infrastruktur perdagangan saling berkointegrasi pada tingkat level signifikansi $(\alpha=5 \%)$. Setelah adanya hubungan jangka panjang antar variabel pada uji kointegrasi, bisa dilanjutkan dengan pengujian regresi jangka panjang dan regresi jangka pendek.

Tabel 4. Hasil Analisis Persamaan Jangka Panjang

\begin{tabular}{lllll}
\hline $\begin{array}{l}\text { Dependent Variable: PAD } \\
\text { Method: Least Squares }\end{array}$ \\
$\begin{array}{l}\text { Date: 01/11/20 Time: 14:52 } \\
\text { Sample: 2010Q1 2017Q4 }\end{array}$ & & & \\
Included observations: 32 & & & & \\
\hline \hline Variable & Coefficient & Std. Error & t-Statistic & Prob. \\
\hline \hline C & 2.468238 & 3.278969 & 0.075327 & 0.9405 \\
JALAN & 0.212514 & 0.499906 & 0.425108 & 0.6741 \\
PARIWISATA & 1.682386 & 13.57834 & 0.123902 & 0.9023 \\
KESEHATAN & 6.841736 & 0.896969 & 7.627618 & 0.0000 \\
PERDAGANGAN & 11.19569 & 1.927024 & 5.809834 & 0.0000 \\
\hline \hline & & & & \\
R-squared & 0.972552 & Mean dependent var & 7.139696 \\
Adjusted R-squared & 0.968485 & S.D. dependent var & 4.558970 \\
S.E. of regression & 8.089869 & Akaike info criterion & 53.21091 \\
Sum squared resid & 1.769778 & Schwarz criterion & 53.43993 \\
Log likelihood & -846.3745 & Hannan-Quinn criter. & 53.28682 \\
F-statistic & 239.1657 & Durbin-Watson stat & 1.466070 \\
Prob(F-statistic) & 0.000000 & & & \\
\hline
\end{tabular}


127 Tabel diatas merupakan hasil analisis jangka 127anjang hubungan antar variabel pendapatan asli daerah, infrastruktur jalan, infrastruktur pariwisata, infrastruktur kesehatan dan infrastruktur perdagangan. Hasil uji kointegrasi mengidentifikasikan adanya kointegrasi berarti terdapat hubungan jangka 127anjang antar variabel. Model analisis jangka 127anjang dalam penelitian ini dapat diperoleh persamaan jangka 127anjang sebagai berikut:

$\mathrm{PAD}=$ 2,46 + 0,212514 JAL + 1,682386 PAR + 6,81736 KES + 11,19569 PER + e

Uji pengaruh simultan dilakukan dengan Uji F, berdasarkan tabel diatas diketauhi bahwa nilai prob(F-statistic) atau uji F sebesar 0,0000. Dapat disimpulkan bahwa nilai F-statistic berada dibawah nilai $\alpha=5 \%$ dan secara statistik dapat dikatakan signifikan. Hal ini menunjukan bahwa variabel infrastruktur jalan, infrastruktur pariwisata, infrastruktur kesehatan dan infrastruktur perdagangan bersama-sama berpengaruh terhadap pendapatan asli daerah dalam jangka panjang.

Tabel 5. Hasil Analsis Persamaan Jangka Pendek

Dependent Variable: PAD

Method: Least Squares

Date: 01/11/19 Time: 15:37

Sample (adjusted): 2010Q3 2017Q4

Included observations: 30 after adjustments

\begin{tabular}{|c|c|c|c|c|}
\hline Variable & Coefficient & Std. Error & t-Statistic & Prob. \\
\hline $\mathrm{C}$ & -2.437980 & 3.775956 & -0.643818 & 0.5258 \\
\hline JALAN & -0.084184 & 0.496078 & -0.169699 & 0.8667 \\
\hline PARIWISATA & 13.05139 & 14.13206 & 0.923531 & 0.3649 \\
\hline KESEHATAN & 7.205337 & 0.872832 & 8.255124 & 0.0000 \\
\hline PERDAGANGAN & 11.95470 & 1.901164 & 6.288098 & 0.0000 \\
\hline \multirow[t]{2}{*}{$\mathrm{ECT}(-1)$} & 0.499416 & 0.219378 & 2.276512 & 0.0320 \\
\hline & \multicolumn{3}{|c|}{ Mean dependent } & \\
\hline \multirow{2}{*}{$\begin{array}{l}\text { R-squared } \\
\text { Adjusted R-squared }\end{array}$} & 0.974346 & var & 7.546875 & \\
\hline & 0.969001 & $\begin{array}{l}\text { S.D. dependent va } \\
\text { Akaike inf }\end{array}$ & $\begin{array}{l}\operatorname{ar} 4.399685 \\
\text { fo }\end{array}$ & \\
\hline S.E. of regression & 7.736869 & criterion & 53.15591 & \\
\hline Sum squared resid & 1.435968 & $\begin{array}{l}\text { Schwarz criterion } \\
\text { Hannan-Quinn }\end{array}$ & 53.43615 & \\
\hline Log likelihood & -791.3386 & $\begin{array}{l}\text { criter. } \\
\text { Durbin-Watson }\end{array}$ & 53.24556 & \\
\hline F-statistic & 182.3043 & stat & 1.958065 & \\
\hline Prob(F-statistic) & 0.000000 & & & \\
\hline
\end{tabular}

RAAR

Vol.1 No.2

Tabel diatas merupakan hasil regresi, nilai koefisien ECT (PAD) sebesar 0,499416 apabila dilihat dari taraf signifikansi hasil regresi ECT dari nilai prob ECT sebesar 0,0320 yang artinya bahwa variabel ini bisa dibilang signifikan atau dibawah taraf signifikansi $\alpha=5 \%$. Dapat disimpulkan bahwa model ECM tersebut cocok dan tepat dalam penelitian ini. Oleh 
karenanya pengujian ECM dikatakan valid, berikut merupakan model analisis jangka pendek dalam penelitian ini dapat diperoleh persamaan jangka pendek sebagai berikut:

$\triangle$ PAD $=\quad-2,43-0,084184 \quad \Delta$ JAL+13,05139 $\Delta$ PAR+7,205337 $\Delta$ KES+11,95470

\section{PEMBAHASAN}

Berdasarkan hasil uji $\mathrm{F}$ untuk jangka panjang menunjukan bahwa pembangunan infrastruktur jalan, infrastruktur pariwisata, infrastruktur kesehatan dan infrastruktur perdagangan secara simultan berpengaruh signifikan terhadap pendapatan asli daerah tahun 2010 - 2017 dan nilai $\mathrm{R}^{2}$ pada jangka panjang sebesar 97,43\% dapat diterima dengan nilai $\mathrm{R}^{2}$ tinggi, hal ini dikarenakan variabel infrastruktur jalan, infrastruktur pariwisata, infrastruktur kesehatan dan infrastruktur perdagangan berpengaruh tinggi terhadap pendapatan asli daerah. Sedangkan untuk jangka pendek berdasarkan hasil uji F menunjukan bahwa pembangunan infrastruktur jalan, infrastruktur pariwisata, infrastruktur kesehatan dan infrastruktur perdagangan secara simultan berpengaruh signifikan terhadap pendapatan asli daerah tahun 2010 - 2017 dan nilai $\mathrm{R}^{2}$ sebesar $97,25 \%$ yang menunjukan diterima dengan nilai $\mathrm{R}^{2}$ tinggi, hal ini terjadi karena variabel infrastruktur jalan, infrastruktur pariwisata, infrastruktur kesehatan dan infrastruktur perdagangan berpengaruh tinggi terhadap pendapatan asli daerah.

Terdapat kajian teori yang dikemukakan (Gujararti dan Porter, 2012) dalam analisis, tidaklah penting untuk memperoleh nilai $\mathrm{R}^{2}$ yang tinggi, tetapi sebenarnya untuk mengetauhi apakah koefisien regresi yang kita peroleh secara statistik signifikan atau terdapat indikasi berlawanan dari ekspetasi sebelumnya. Oleh karena itu, para peneliti seharusnya lebih memperhatikan tentang relevansi logis atau teoritis dari variabel independen terhadap variabel dependen dan signifikansi statistiknya. Jika (dalam perhitungan) mendapatkan nilai $\mathrm{R}^{2}$ yang tinggi hal itu berarti baik.

\section{Pengaruh Pembangunan Infrastruktur Jalan terhadap Pendapatan Asli Daerah}

Pada dasarnya pembangunan infrastruktur jalan untuk meningkatkan kelancaran arus lalu lintas barang dan orang dalam menghubungkan suatu daerah ke daerah disekitarnya, dengan semakin lancarnya arus lalu lintas maka semakin baik efisiensi waktu pengiriman barang dan semakin baik pula laju perekonomian didaerah yang bisa untuk meningkatkan pendapatan daerah itu sendiri. Semakin lancarnya transportasi akan menimbulkan dampak baik untuk pergerakan barang maupun orang.

Berdasarkan hasil analisis estimasi jangka panjang diketauhi bahwa infrastruktur jalan menghasilkan $t_{\text {hitung }}=0,425108<\mathrm{t}_{\text {tabel }}=1,703$ atau signifikansi $0,6741>0,05$ dari hasil penelitian ini menunjukan bahwa tidak terdapat pengaruh yang signifikan antara pembangunan infrastruktur jalan terhadap pendapatan asli daerah. Adapun fokus pekerjaan di anggaran tersebut terdapat dua sektor, yaitu infrastruktur kawasan pinggiran penghubung ke daerah tetangga dan penataan tengah kota. Untuk penataan tengah kota atau jalan-jalan protokol dari catatan Dinas Pekerjaan Umum (DPU) Kota Semarang yang menyebutkan jika presentase kondisi jalan baik di Kota Semarang tahun 2011 sebesar 46\% dan data terakhir jalan baik pada tahun 2017 telah mencapai 88,7\%, capaian tersebut naik hampir dua kali lipat.

Dengan begitu karena pada tahun 2019 kondisi jalan baik di Kota Semarang telah Vol.1 No.2 mencapai $88,7 \%$, maka untuk infrastruktur jalan di Kota Semarang tidak dapat 
meningkatkan pendapatan asli daerah. Sedangkan menurut hasil analisis estimasi jangka pendek diketauhi bahwa infrastruktur jalan menghasilkan $t_{\text {hitung }}=-0,169699<t_{\text {tabel }}=1,708$ atau signifikansi 0,8667>0,05 dari hasil penelitian ini menunjukan bahwa tidak terdapat pengaruh yang signifikan antara pembangunan infrastruktur jalan terhadap pendapatan asli daerah. Hal ini dikarenakan penggunaan pada pembangunan jalan pada jangka pendek belum bisa dirasakan oleh masyarakat, sebab tidak semua masyarakat dapat menikmati pembangunan jalan. Untuk jangka pendek mungkin mengakibatkan terhambatnya perekonomian daerah, karena belum bisa dirasakan sepenuhnya. Temuan ini didukung oleh penelitian dari (Ketut, 2016) pembangunan infrastruktur jalan tidak berpengaruh signifikan terhadap pertumbuhan PRDB.

\section{Pengaruh Pembangunan Infrastruktur Pariwisata terhadap Pendapatan Asli Daerah}

Infrastruktur pariwisata sebagai aspek yang penting dalam pencapaian pembangunan, baik dalam bidang sosial maupun dalam bidang ekonomi. Selain itu, prasarana perlu disediakan sebagai kebutuhan dasar dan dapat menggerakkan pertumbuhan ekonomi. Pengembangan sektor pariwisata sangat terkait dan bergantung pada perkembangan infrastruktur yang tersedia. Setelah beberapa aspek dari sarana dan prasarana telah terlaksana akan meningkatkan perekonomian untuk menghasilkan pendapatan yang besar bagi daerah. Berdasarkan hasil analisis estimasi jangka panjang diketauhi bahwa infrastruktur pariwisata menghasilkan $\mathrm{t}_{\text {hitung }}=0,123902<\mathrm{t}_{\text {tabel }}=1,703$ atau signifikansi $0,9023>0,05$, dari hasil penelitian ini menunjukan bahwa tidak terdapat pengaruh yang signifikan antara pembangunan infrastruktur pariwisata terhadap pendapatan asli daerah. Sebagai contoh destinasi wisata desa kandri yang belum dapat dioptimalkan secara baik oleh pemerintah Kota Semarang, minimnya mempromosikan destinasi wisata diwilayahnya menjadi sedikitnya jumlah wisatawan yang berkunjung untuk meningkatkan pendapatan dan belum naiknya secara signifikan karena faktor infrastruktur tempat wisata yang belum baik, misalknya pengelolaan, penataan dan konsep tempat wisata itu sendiri. Pariwisata menyimpan potensi yang sangat besar untuk meningkatkan pendapatan daerah. Sedangkan menurut hasil analisis estimasi jangka pendek diketauhi bahwa infrastruktur pariwisata menghasilkan $\mathrm{t}_{\text {hitung }}=0,923531<\mathrm{t}_{\text {tabel }}=1,708$ atau signifikansi $0,3649>0,05$, dari hasil penelitian ini menunjukan bahwa tidak terdapat pengaruh yang signifikan antara pembangunan infrastruktur pariwisata terhadap pendapatan asli daerah. Hal ini dikarenakan banyaknya tempat wisata yang berpotensi dalam meningkatkan kunjungan wisatawan, tetapi kurangnya pengelolaan dari pemerintah seperti: goa kreo dan waduk jatibarang. Kurangnya gerakan yang bersinergi antara pemerintah dan masyarakat menjadikan potensi wisata menjadi tertinggal atau kurang diperhatikan oleh pemerintah.

Temuan ini didukung oleh penelitian dari (Tumpal, 2014) pariwisata tidak berpengaruh signifikan terhadap pertumbuhan asset, dan penelitian dari (Abby, 2018) menunjukkan hasil bahwa infrastruktur pariwisata tidak berpengaruh signifikan terhadap Pendapatan Asli Daerah (PAD).

\section{Pengaruh Pembangunan Infrastruktur Kesehatan terhadap Pendapatan Asli Daerah}

Pembangunan infrastruktur kesehatan menjadi bagian integral dari pembangunan nasional karena bidang kesehatan menyentuh hampir seluruh aspek kehidupan manusia secara berkesinambungan, yang merupakan suatu rangkaian pembangunan yang menyeluruh,

RAAR Vol.1 No.2 terpadu dan terarah. Pembangunan ini merupakan upaya untuk tercapainya kesadaran, kemauan dan kemampuan hidup sehat sehingga dimasa mendatang tercipta penerus yang bermutu sebagai modal penting pembangunan nasional.

Berdasarkan hasil analisis estimasi jangka panjang diketauhi bahwa infrastruktur kesehatan menghasilkan $t_{\text {hitung }}=7,627618>t_{\text {tabel }}=1,703$ atau signifikansi $0,0000<0,05$, dari hasil 
penelitian ini menunjukan bahwa terdapat pengaruh yang signifikan antara pembangunan infrastruktur kesehatan terhadap pendapatan asli daerah. Adanya pembangunan dan perbaikan puskesmas dan rumah sakit disetiap titik strategis yang mudah dijangkau oleh masyarakat Kota Semarang beserta dengan fasilitas-fasilitas kesehatan, akan tercapainya sumber daya manusia yang sehat. Banyaknya inovasi yang dilakukan pemerintah daerah berupa layanan cepat untuk situasi yang darurat akan kesehatan, seperti: Ambulance Hebat dimana masyarakat bisa menghubungi pelayanan tersebut disaat darurat. Sedangkan menurut hasil analisis estimasi jangka pendek diketauhi bahwa infrastruktur kesehatan menghasilkan $t_{\text {hitung }}=8,255124>\mathrm{t}_{\text {tabel }}=1,708$ atau signifikansi $0,0000<0,05$, dari hasil penelitian ini menunjukan bahwa terdapat pengaruh yang signifikan antara pembangunan infrastruktur kesehatan terhadap pendapatan asli daerah. Hal ini dikarenakan meratanya masyarakat yang mendapat bantuan dan layanan kesehatan dari pemerintah, serta pengadaan alat-alat kesehatan yang memadai di rumah sakit dan puskesmas. Dengan begitu produktivitas masyarakat dalam bekerja dapat mempengaruhi pendapatan yang didapat masyarakat menjadi optimal.

Temuan ini didukung oleh penelitian dari (Nurudeen dan Usman, 2010) belanja pemerintah dibidang kesehatan berpengaruh positif signifikan terhadap pertumbuhan ekonomi, lalu penelitian (Warsilan, 2014) yang menyimpulkan belanja pemerintah dibidang kesehatan berpengaruh signifikan terhadap pertumbuhan ekonomi di Kota Samarinda.

\section{Pengaruh Pembangunan Infrastruktur Terhadap Pendapatan Asli Daerah}

Infrastruktur perdagangan merupakan salah satu yang terpenting untuk dilakukan pembangunan, karena setiap hari terjadinya transaksi jual beli di pasar tradisional. Semakin banyak pasar tradisional yang terletak di daerah strategis akan mendatangkan pendapatan yang semakin tinggi.

Berdasarkan hasil analisis estimasi jangka panjang diketauhi bahwa infrastruktur perdagangan menghasilkan $t_{\text {hitung }}=5,809834>t_{\text {tabel }}=1,703$ atau signifikansi $0,0000<$ 0,05 , dari hasil penelitian ini menunjukan bahwa terdapat pengaruh yang signifikan antara pembangunan infrastruktur perdagangan terhadap pendapatan asli daerah. Hal ini pembangunan dan perbaikan pasar di Kota Semarang dilakukan secara merata disetiap titiknya dan mudah dijangkau oleh masyarakat sekitar. Konsep dan penataan pasar juga sangat diperhatikan secara baik untuk menarik minat masyarakat berbelanja kebutuhan sehari-hari di pasar. Sedangkan menutur hasil analisis estimasi jangka pendek diketauhi bahwa infrastruktur perdagangan menghasilkan $t_{\text {hitung }}=6,288098>t_{\text {tabel }}=1,708$ atau signifikansi $0,0000<0,05$, dari hasil penelitian ini menunjukan bahwa terdapat pengaruh yang signifikan antara pembangunan infrastruktur perdagangan terhadap pendapatan asli daerah. Hal ini dikarenakan pemerintah daerah secara cepat dan tanggap dalam merespon apa yang dibutuhkan oleh pedagangan seperti: merelokasi pasar supaya tetap bisa melakukan transaksi disetiap harinya disaat pasar akan dilakukan revitalisasi. Temuan ini didukung oleh penelitian dari (Agus, 2009) menunjukkan sektor perdagangan berkontribusi besar dalam pembangunan daerah. 


\section{Simpulan}

Berdasarkan hasil analisis dan pembahasan dari penelitian ini, maka dapat ditarik beberapa kesimpulan sebagai berikut:

1. Hasil analisis secara simultan variabel infrastruktur jalan, infrastruktur pariwisata, infrastruktur kesehatan dan infrastruktur perdagangan berpengaruh signifikan terhadap pendapatan asli daerah dalam jangka panjang maupun jangka pendek.

2. Hasil analisis secara parsial menunjukan bahwa variabel infrastruktur kesehatan dan infrastruktur perdagangan berpengaruh signifikan terhadap pendapatan asli daerah dalam jangka panjang dan jangka pendek.

3. Untuk hasil analisis parsial variabel infrastruktur jalan dan infrastruktur pariwisata tidak berpengaruh signifikan terhadap pendapatan asli daerah dalam jangka panjang dan jangka pendek.

\section{Saran}

Saran untuk penelitian yang akan datang sebaiknya tidak hanya melihat dari pembangunan infrastruktur fisik saja tetapi juga perlu melihat pembangunan insfrastruktur non fisiknya.

\section{REFERENSI}

Adi, Priyo Hari. 2006. Hubungan Antara Pertumbuhan Ekonomi Daerah, Belanja Pembangunan Dan Pendapatan Asli Daerah (Studi pada Kabupaten dan Kota se Jawa-Bali). Simposium Nasional Akuntansi IX Padang.

Ariefianto, M. D. 2012. EKONOMETRIKA Esensi dan Aplikasi Dengan Menggunakan Eviews. Erlangga: Jakarta.

Badan Pusat Statistik. Laporan Penduduk Kota Semarang 2017. Semarang.

Dewi, Elita. 2002. Identifikasi Sumber Pendapatan Asli Daerah dalam Rangka Pelaksanaan Otonomi Daerah. Jurnal Ilmu Sosial dan Ilmu Politik. Universitas Sumatera Utara.

Direktorat Jendral Perimbangan Keuangan (DJPK). http://www.djpk.kemenkeu.go.id.

Elmi, B. 2002. Keuangan Pemerintahan Daerah Otonomi di Indonesia. Indonesia Press: Jakarta.

Ghozali. 2018. Aplikasi Analisis Multivariate Dengan Program SPSS. Universitas Diponegoro : Semarang.

Green, Keith. 2005. Decentralization and Good Governance : The Case of Indonesia. MPRA Paper No. 18097. Munich Personal RePec Archive.

Herman, J. 2014. Implementasi Pembangunan Infrastruktur Dalam Rangka Percepatan Pembangunan Daerah. Ejournal Administrartive Reform.

Kuncoro, M. 2012. Perencanaan Daerah Bagaimana Membangun Ekonomi Lokal, Kota dan Kawasan. Salemba Empat : Jakarta.

RAAR

Vol.1 No.2

Moh, Abby. 2018. Analisis Pembangunan Infrastruktur Daerah Terhadap Pendapatan Asli Daerah Di Kabupaten Tasikmalaya. Jurnal Ekonomi. Universitas Islam Indonesia.

Peraturan Menteri Dalam Negeri Nomor 13 Tahun 2006. Tentang Pedoman Pengelolaan Keuangan Daerah. 
Peraturan Pemerintah Nomor 38 Tahun 2007. Tentang Pembagian Urusan Pemerintahan, Pemerintahan Provinsi dan Pemerintahan Daerah Kabupaten/Kota.

Peraturan Pemerintah Nomor 58 Tahun 2005. Tentang Pengelolaan Keuangan Daerah.

Peraturan Pemerintah Nomor 66 Tahun 2001, Tentang Retribusi Daerah.

Pitana, I Gede Gayatri. 2005. Sosiologi Pariwisata. Andi : Yogyakarta.

Purnama, D., \& Azizah, S. N. (2019). Implementasi Sistem Keuangan Desa Berbasis Akuntansi Keperilakuan. Jurnal Kajian Akuntansi, 3(2), 160-169.

Putro, N. S. 2011. Pengaruh pertumbuhan ekonomi, PAD dan Dana Alokasi Umum Terhadap Pengalokasian Anggaran Belanja Modal. Jurnal Ekonomi. http://www.eprints.undip.ac.id.

Rondinelli, Denis A. and G. Shabir Cheema. (1983). Implementing Decentralization Policies. SAGE Publication : California.

Seymour, Richard and Sarah Turner. (2002). Otonomi Daerah : Indonesia's Decentralication Experiment. New Zealand Journal of Asian Studies.

Sitompul, R. 1996. Keuangan Negara. Erlangga : Jakarta.

Soamale, M. 2013. Pengaruh Pendapatan Asli Daerah Terhadap Penyelenggaraan Pembangunan Daerah (Studi Di Kabupaten Kepulauan Sula). Ejournal.

Subagya, A. 2017. Mekanisme dan Implementasi Otonomi Daerah. www.arupa.or.id.

Sugiyono. 2016. Statistika Untuk Penelitian. Alfabeta : Bandung.

Suradinata, E. 1998. Manajemen Pemerintahan dan Otonomi Daerah. Ramadan : Bandung.

Suratno, Putro. 2010. Pengaruh Pertumbuhan Ekonomi, Pendapatan Asli Daerah dan Dana Alokasi Umum Terhadap Pengalokasian Anggaran Belanja Modal (Studi Kasus Kab/Kota di Provinsi Jawa Tengah). Sustainable Development. Vol 4 No 3.

Susanto. 2005. Konribusi PAD Terhadap Besarnya Belanja Pembangunan Daerah (Studi Kasus Kota Pemalang).

Widarjono, A. 2013. Ekonometrika Teori dan Aplikasi. UPP STIM YKPN : Yogyakarta.

Undang-Undang Nomor 23 Tahun 2014. Tentang Pemerintahan Daerah.

Undang-Undang Nomor 25 Tahun 1999. Tentang Perimbangan Keuangan Pusat dan Daerah.

Undang-Undang Nomor 28 Tahun 2009. Tentang Pajak Daerah dan Retribusi Daerah.

Undang-Undang Nomor 33 Tahun 2004. Tentang Mengatur Perimbangan Keuangan Antara Pemerintah Pusat dan Pemerintah Daerah. 